\title{
SCREENING SOME LOCAL AND INTRODUCED PUMPKIN (Cucurbita moschata) GENOTYPES FOR EARLINESS AND FRUIT YIELD TRAITS \\ Obiadalla-Ali, H. A. ${ }^{1}$; Nevein A. El-Sawah ${ }^{2}$ and A. A. Helaly ${ }^{3}$ \\ 1-Dept. Horticulture, Fac. of Agric., Sohag University, Sohag, Egypt \\ 2-Dept. Horticulture, Fac. of Agric., Fayoum University, Fayoum, Egypt. \\ 3-Dept. Horticulture, Fac. of Agric., Azhar University, Cairo, Egypt.
}

\begin{abstract}
Fifteen genotypes of pumpkin (Cucurbita moschata Duchesne) were screened for earliness and fruit yield at the Experimental Farm, Faculty of Agriculture, Sohag University during the two successive seasons; 2007 and 2008. There were significant differences among genotypes for all studied characters. Etamp cultivar had the longest vine length and leaves number per plant, while Butternut cultivar had the shortest vine length in both seasons. Butternut cultivar gave the highest value of sex ratio, while the lowest one was recorded by El-Mansoura cv. Butternut cultivar was the earliest in both male and female flowers, while genotype Khartoum (Sudan) accession was the latest in male and female flowers in both seasons. Etamp cultivar bore the first male and female flowers on the highest node number, while Butternut cultivar produced the $1^{\text {st }}$ male and female flowers on the lowest node number in both seasons. Pepa (Beni Suef) accession had the highest number of nodes between the $1^{\text {st }}$ male and $1^{\text {st }}$ female flowers while; Butternut cultivar had the lowest number of nodes between the $1^{\text {st }}$ male and the $1^{\text {st }}$ female flowers in both seasons. Desuk (Kafr El-Sheikh) accession gave the largest number of days between the $1^{\text {st }}$ male and the $1^{\text {st }}$ female flowers anthesis, while Butternut cultivar gave the lowest number of days between the $1^{\text {st }}$ male and the $1^{\text {st }}$ female flowers anthesis. Butternut cultivar gave the highest sex ratio, while El-Mansoura accession gave the lowest sex ratio in both seasons. Etamp cultivar fruits were longest, while those of accession Omdurman (Sudan) were shortest in both seasons. Etamp cultivar was greatest in fruit diameter, while Butternut accession was smallest in fruit diameter in both seasons. Etamp cultivar was heaviest fruit weight, while Butternut cultivar was lowest in fruit weight in both seasons. Etamp cultivar gave the highest value for flesh thickness while, Butternut cultivar showed the lowest value for this character in both seasons. Etamp cultivar exceeded all other genotypes in total fruit yield, while Butternut cultivar produced the lowest fruit yield in both seasons. Butternut cultivar gave the highest value for total soluble solids\%, while Bardis (Sohag) accession showed the lowest value for this character, in both seasons. Thus, the results of this study could be useful in breeding programs for improving local pumpkin genotypes under Upper Egypt conditions.
\end{abstract}

Keywords: Earliness, Yield, Flesh thickness, Landraces and Total soluble solids.

\section{INTRODUCTION}

Local pumpkin (Cucurbita moschata Duchesne) landraces spread over a wide range of environments in Egypt and many of other countries and they are utilized in many local dishes and food industries. In Egypt, local pumpkin has been grown widely for many decades and can be considered one of the major vegetable crops. It is consumed in different local dishes and some food industries such as jams, purees and cakes. In Egypt, about 91816 feddan (Ministry of Agriculture and Land Reclamation, Egypt, 2005). are cultivated 
annually with Cucurbita. The seeds of several Cucurbita species are relatively rich in lipids and proteins and make a nutritious snack when roasted and salted. In some African countries shoot tips of cucurbits, are cooked and eaten as vegetable. In America, the majority of pumpkin is grown for the Halloween sales and is for ornament only, not for human consumption. Its popularity is increasing to day and the demand for pumpkin is being increased. It is a tasty dish and contains relatively high amount of biologically active compounds which is essential for health protection. In human nutrition, $\beta$ carotene, enzymatically converted into vitamin $A$, is of a great biochemical and physiological importance and is believed to impede some forms of cancer.

Many investigators studied the vegetative and yield variations traits among cucurbit species (Doijode et al., 1982; Rana et al., 1985; Doijode and Sulladmath, 1986; Mondal et al., 1989; Bost et al., 1991; Swamy and Dutta, 1991; Prasad and Singh, 1992; Damarany et al., 1995; Olson et al., 1995; Mohanty and Mishra, 1999; Vallejo et al., 1999 a\&b; Keinath and DuBose, 2000; Mohanty, 2000; Alsadon et al., 2002; White, 2002 and Mostafa, 2006).

As a market demand for pumpkin has recently increased in Egypt because of their prices are becoming high and more growers are attempting to produce the crop. In an effort to maximize profitability; growers are exploring ways to increase yield per unit area.

Researchers and farmers have noticed unstable fruit characteristics of local pumpkin genotypes grown in Egypt may be due to the cross pollination that occur in cucurbits crops. In general, there has been a limited work on the improvement of cucurbits in Egypt. Ibrahim and co-workers were among the pioneers to initiate the cucurbitaceae improvement program. They have released two sour-sweet melon (Ibrahim and Al-Zeir, 1992) and two desertadapted winter squash (Ibrahim et al., 1996) cultivars. The objective of this study was to evaluate the performance of fifteen local and introduced pumpkin genotypes for earliness and fruit yield

\section{MATERIALS AND METHODS}

\section{Plant materials.}

Fruits of fifteen locally and introduced grown pumpkin accessions were collected from October 2005 to November 2006 from different regions of Egypt where they have been commonly grown for several decades. Out of fifteen accessions, 11 were collected from various provinces of Egypt extending from El-Mansoura in middle Delta to Qus, Qena, south in upper Egypt, and from Ismailia east to Desuk (Kafr El-Sheikh) northwest of Delta. The fifteen accessions, also, included two imported U.S.A cvs. (Etamp and Butternut) and two accessions from Sudan (Khartoum and Omdurman). The locally and introduced grown pumpkin accessions exhibit various in fruit skin color, fruit flesh color, fruit size, fruit shape and fruit shell (Figure 1). These 15 pumpkin accessions are presented in Table (1). 
J. Agric. Sci. Mansoura Univ., 34 (6), June, 2009

1

6641 
Obiadalla-Ali, H. A. et al.

Figure (1): Fruit characteristics of fifteen pumpkin accessions grown at Faculty of Agriculture, Sohag University, El-Kawser, Sohag 
Seeds were collected, washed with water, air-dried and kept at room temperature until the time of planting. Seed for all traits were obtained from the same seed lots during the present study.

Field layout.

Two years field trials (2007 and 2008) were executed at the Experimental Farm of Faculty of Agriculture, Sohag University, El-Kawser, Sohag, Egypt, to evaluate the 15 selected pumpkin accessions for earliness, fruit output and fruit components.

The experimental design was a randomized complete block with three replications. Each experimental unit (plot) consisted of two raised beds, each 3 meter long and $4 \mathrm{~m}$ apart (width), with plants $0.70 \mathrm{~cm}$ apart in the bed. Thus, each plot contained 8 plants occupying $24 \mathrm{~m}^{2}$.

Seeds were directly in the open field planted in both seasons. The sowing date was August $25^{\text {th }}$ in 2007 and 2008 in both seasons. At planting date, 2-4 seeds were sown in every hill on one side of the bed. Thinning of hills was carried out twice, the first at the two leaf stage and the second one at the 4-5 true leaf stage, where finally one plant was left per each hill. Fertilization, furrow irrigation and other cultural practices were carried out as recommended for commercial production of pumpkin.

\section{Characteristics measurements.}

Vegetative growth.

Vegetative growth data were taken at 90 days from sowing and the following characters were measured; vine length $(\mathrm{m})$ and number of leaves per plant.

Reproductive growth.

Sex ratio percentage of opened flowers (male and female) that opened during the period from the start of first anthesis to 90 days old and sex ratio was estimated as (total number of females / total number of males) $x 100$.

\section{Earliness of flowering.}

Earliness of flowering was estimated by: number of days from sowing to the first male flower anthesis, node number at which the first male flower opened, number of days to the first female flower anthesis, node number at which the $1^{\text {st }}$ pistillate flower opened, number of nodes between the appearance of the first open male to the first open pistillate flower and number of days elapsed between the first male and the first female flower anthesis.

\section{Fruit characteristics.}

Fruits were harvested at full maturity, transferred to the laboratory and kept at room temperature until they were evaluated. Four fruits were randomly assigned in each plot in the main field trial and the following descriptions were recorded: fruit weight $(\mathrm{kg})$, Fruit length $(\mathrm{cm})$ for the longitudinal axis starting from the peduncle junction to the blossom end, Fruit diameter $(\mathrm{cm})$ at the maximum fruit diameter, Flesh thickness of fruit $(\mathrm{cm})$, average of three measures, at the beginning of the fruit cavity, at the maximum fruit diameter, and at the blossom end and percent of total soluble solids (TSS\%) were measured using a hand heldle refractometer (HRN-32, 
Kruss, Germany). Flesh samples were taken from three different parts of fruit.

Crop fruit yield.

All fruits produced in each plot were counted and weighed and then the total fruit output per feddan was estimated as (Fruit yield in tones per feddan).

\section{Statistical analysis}

All recorded data were tabulated and statistically analyzed according to Snedecor and Cochran (1967), using Duncan (1958) for comparing various treatment means.

\section{RESULTS AND DISCUSSION}

\section{Vegetative characteristics}

1- Vine length.

Vine length of the 15 pumpkin accessions over two seasons is presented in Table (2). Significant differences in vine length were found among pumpkin accessions in both seasons. Etamp cultivar had the longest (5.66 and 5.67) vine length in the first and second seasons, respectively. While, Butternut cultivar had the shortest (3.35) vine length in both seasons. These results are in accordance with those found by Carle et al. (2000); Alsadon et al. (2002); Mukunda et al. (2003) and Mostafa (2006).

\section{2- Number of leaves per plant.}

Leaf production per plant recorded after 90 days from sowing for the 15 accessions of pumpkin over two successive seasons is shown in Table (2). There were significant differences in this character among different accessions in both seasons. The fewest (128 and 127) number of leaves/plant was recorded for Butternut cultivar in the first and second seasons, respectively. Etamp cultivar gave the highest value (221) for this character in both seasons. These results were in line with those found by Mukunda, et al. (2003) and Mostafa (2006).

Reproductive characteristics.

Sex ratio percentage.

Number of female to male flower percent (sex ratio) was recorded till 90 days from sowing for the 15 pumpkin accessions is presented in Table (2). Significant differences in sex ratio were found among pumpkin accessions in both seasons. Butternut cultivar gave the highest (9.70 and $9.41 \%)$ sex ratio in the first and second seasons, respectively. The lowest sex ratio values (6.54 and 6.79\%) were obtained from El-Mansoura accession in the first and second seasons, respectively. These results were in line with these found by Mukunda, et al. (2003) and Mostafa (2006).

\section{Earliness characteristics.}

1- Number of days from sowing to the first male flower anthesis.

The results in Table (2) clearly explain that number of days to the first male flower opening for the 15 pumpkin genotypes significantly differed in both seasons. 
J. Agric. Sci. Mansoura Univ., 34 (6), June, 2009

2

6645 
Butternut cultivar was the earliest (45.33 and 45.00 days) in first male flower appearance in the first and second seasons, respectively. While, Khartoum (Sudan) accession was the latest (58.00 and 57.67 days) for this character in the first and second seasons, respectively. These results are in accordance with those found by Carle et al. (2000), Mukunda et al. (2003) and Mostafa (2006).

\section{2- Node number of the first male flower.}

The results in Table (2) demonstrate the number of node at which the $1^{\text {st }}$ male flower was borne for the 15 pumpkin genotypes during the two seasons. The results revealed significant differences in this character among the genotypes. The lowest node number $(4.33$ and 4.00$)$ at which the $1^{\text {st }}$ male flower appeared was shown by Butternut cultivar in the first and second seasons, respectively. While, the highest node number (7.00 and 7.33) at which the $1^{\text {st }}$ male flower appeared was shown by Etamp cultivar in the first and second seasons, respectively. These results were in line with these found by Mukunda, et al. (2003) and Mostafa (2006).

\section{3- Number of days to the first female flower anthesis.}

The result in Table (3) clearly shows that that number of days to the first female flower opening for the 15 pumpkin genotypes significantly differed in both seasons. Butternut cultivar was the earliest (43.00 and 42.67 days) in first female flower appearance in the first and second seasons, respectively. While, Khartoum (Sudan) accession was the latest (63.00 and 63.67 days) for this character in the first and second seasons, respectively. Same general trends were reported by Mukunda, et al. (2003) and Mostafa (2006).

\section{4- Node number of the first female flower.}

Result in Table (3) clearly demonstrates the number of node bearing the first female flower of the 15 pumpkin genotypes in two successive seasons. There were significant differences concerning this character among the genotypes in both seasons. Etamp cultivar had the highest value (18.67 and 18.33) in node number bearing the $1^{\text {st }}$ female flower in the first and second seasons, respectively. While, Butternut cultivar had the lowest value ( 7.00 and 6.67) in node number bearing the $1^{\text {st }}$ female flower in the first and second seasons, respectively. These results were in line with these found by Mukunda, et al. (2003) and Mostafa (2006).

5 - Number of nodes between the $1^{\text {st }}$ male and the $1^{\text {st }}$ female flowers.

Table (3) presents the number of nodes between the $1^{\text {st }}$ male and $1^{\text {st }}$ female flowers for the 15 pumpkin accessions in two successive seasons. Results showed significant differences concerning this character among the accessions in both seasons. The lowest (2.67) node number between the $1^{\text {st }}$ male and the $1^{\text {st }}$ female flowers appearance was shown by Butternut cultivar in the first and second seasons, respectively. The highest (12.33 and 11.67) number of nodes between the $1^{\text {st }}$ male and the $1^{\text {st }}$ female flower was demonstrated by Pepa (Beni Suef) accession. Similar trend results were reported by Mostata (2006).

6- Number of days between the $1^{\text {st }}$ male and female flowers anthesis.

Significant differences were found in number of days between the $1^{\text {st }}$ male and the $1^{\text {st }}$ female flower opening for the 15 accessions in the two seasons (Table 3). The lowest (2.33) number of days were found in Butternut 
cultivar in both seasons. The greatest (7.00 and 7.33) number of days between the $1^{\text {st }}$ male and the $1^{\text {st }}$ female flowers anthesis was recorded for Desuk (Kafr El-Sheikh) accession in the first and second seasons, respectively. Same trend results were obtained by Mostafa (2006).

\section{Fruit characteristics.}

\section{1- Fruit weight.}

The results in Table (3) show that fruit weight for the 15 pumpkin genotypes significantly differed in both seasons. The heaviest fruit weight $(9.80$ and $9.90 \mathrm{~kg}$ ) was exhibited by Etamp cultivar in the first and second seasons, respectively. Butternut cultivar was the lowest in fruit weight $(1.08$ and $1.12 \mathrm{~kg}$ ) in the first and second seasons, respectively. Similar trends were reported by Damarany et al. (1995); Danilchenko et al. (2000); Carle et al. (2000); Alsadon et al. (2002) and Mostafa (2006).

\section{2- Fruit length.}

The results in Table (4) show that fruit length for the 15 pumpkin genotypes differed significantly in both seasons. The longest (51.25 and 51.14 $\mathrm{cm}$ ) fruits were found in Etamp cultivar in the first and second seasons, respectively. The shortest $(13.16$ and $13.10 \mathrm{~cm})$ fruits were produced by Omdurman (Sudan) accession in the first and second seasons, respectively. Similar results were reported by Damarany et al. (1995); Alsadon et al. (2002) and Mostata (2006). On the other hand, this result was disagreed with Mukunda, et al. (2003).

\section{3- Fruit diameter.}

Fruit diameter significantly differed in the 15 pumpkin genotypes in both seasons (Table 4). The highest fruit diameter $(28.23$ and $28.20 \mathrm{~cm})$ was produced by Etamp cultivar in the first and second seasons, respectively. The lowest fruit diameter $(12.09$ and $12.14 \mathrm{~cm}$ ) was shown by Butternut cultivar in the first and second seasons, respectively. Same trend results were obtained by by Damarany et al. (1995); Alsadon et al. (2002) and Mostata (2006). On the other hand, this result was disagreeing with Danilchenko et al. (2000) and Mukunda, et al. (2003).

\section{4- Flesh thickness of the fruit.}

Fruit flesh thickness of the 15 pumpkin genotypes is illustrated in Table (4). There were significant differences in flesh thickness among the genotypes in both years. Etamp cultivar had the highest values $(4.15$ and $4.17 \mathrm{~cm})$ of fruit thickness in the first and second seasons respectively. The lowest flesh thickness $(1.95$ and $1.94 \mathrm{~cm})$ of fruit was given by Butternut cultivar in the first and second seasons, respectively. These results were in line with those found by Mukunda, et al. (2003); Alsadon et al. (2002) and Mostafa (2006).

\section{5- Total soluble solids (TSS\%).}

Data for this character are presented in Table (4). Significant differences were found among the 15 pumpkin accessions during two seasons. Butternut cultivar gave the highest values (6.68 and $6.67 \%)$ for TSS\% in the first and second seasons, respectively. The lowest (4.51and $4.49 \%)$ TSS\% of fruit was given by Bardis (Sohag) accession in the first and second seasons, respectively. These results were similar with those obtained by Carle et al. (2000); Alsadon et al. (2002) and Mostafa (2006). 
Obiadalla-Ali, H. A. et al.

3

6648 
J. Agric. Sci. Mansoura Univ., 34 (6), June, 2009

4

6649 


\section{Yield characteristics.}

Total fruit yield.

Table (4) presents yield in ton/feddan for the 15 pumpkin genotypes during two seasons. Significant differences were found among genotypes in both seasons. The highest yield (39.49 and 39.61 ton) was found in Etamp cultivar in the first and second seasons, respectively. Genotype Butternut cultivar produced the lowest yields (5.18 and 4.85 ton) in the first and second seasons, respectively. Damarany et al. (1995) assessed the performance of 24 pumpkin genotypes under Assuit conditions and they found significant differences in their reproductive growth, fruit yield and mean fruit weight. Same general trends were also reported by Carle et al. (2000); Alsadon et al. (2002) and Mostafa (2006).

\section{CONCLUSION}

From the data presented in this study, it could be concluded that: Etamp cultivar gave the longest vine length, highest number of leaves/plant, heaviest fruit weight, longest fruit length, largest fruit diameter, highest flesh thickness and heaviest total fruit yield. Butternut cultivar was the earliest in both male and female flower, gave the highest value for sex ratio and total soluble solids $\%$.

\section{REFERENCES}

Alsadon A.A.; H.H. Hegazi and I.A. Almousa (2002). Evaluation of locallygrown pumpkin genotypes in the central region of Saudi Arabia. J. King Saud Univ.,

Bost, S.C.; C.A. Mullins; G. Evans; R.A. Straw and K.E. Johnson (1991). Pumpkin cultivar performance under fungicide treated and non-treated conditions. Biol. Cult. Test, 6:28.

Carle, R.B.; D.N. Maynard and L. Wessel-Beaver (2000). Tropical pumpkin hybrid development: landraces to hybrid cultivars. Acta Hort., 510: 95100, USA.

Damarany, A.M.; M.M. Abdulla and M.H. Abdul-Nasr (1995). Yield and yield components of some Cucurbita spp. cultivars and hybrids under Assiut conditions. II. Pumpkin (Cucurbita spp.). Assiut J. Agric. Sci., 26(1): 5971.

Danilchinko, H.; A. Paulauskiene; R. Dris and R. Niskanen (2000). Biochemical composition and processability of pumpkin cultivars. Acta Hort., 510: 493-497.

Doijode, S.D.; U.V. Sulladmath and R.S. Kulkarki (1982). Graphic analysis and genetic diversity for vegetative and reproductive traits in pumpkin (Cucubita moschata Poir.). Mysore J. Agric. Sci., 16(4): 439- 442.

Doijode, S.D. and U.V. Sulladmath (1986). Genetic variability and correlation studies in pumpkin (Cucurbita moschata Poir.). Mysore J. Agric. Sci., 20(1): 59-61.

Duncan, D.B. (1958). Multiple range and Multiple F test. Biometrics, 11: 1-42. 
Ibrahim, A.M and K.A. Al-Zeir (1992). "'Najd I' and Najd II', Two Sour-sweet Melon Cultivars." Hort. Sci., 27(3): 276-277.

Ibrahim, A.M.; A.I. Al-Sulaiman and K.A. Al-Zeir (1996)."'Hamdan' and 'Qasim' Desert-adapted Winter Squashes". Hort. Sci., 31(5): 889890.

Keinath, A.P. and V.B. DuBose (2000). Evaluation of pumpkin cultivars for powdery and downy mildew resistance, virus tolerance and yield. Hort. Sci., 35: 281-285.

Mohanty, B.K. and R.S. Mishra (1999a). Heterosis for yield and yield components in pumpkin (Cucurbita moschata Duch. Ex. Poir). Indian J. Genet., 54(4): 505-510.

Mohanty, B.K. and R.S. Mishra (1999b). Studies on heterosis for flowering attributes in pumpkin (Cucurbita moschata Duch. Ex. Poir). South Indian Hort., 47(1/6): 203-205, India. (C.F. Plant Breed. Abst., 2001, 71(6): 6172).

Mohanty, B.K. (2000). Combining ability for yield and its components in pumpkin. Indian J. Genet. \& Plant Breed., 60(3): 373-379.

Mondal, S.N.; A.K. Rashid; A.K.M.A. Hossain and M.A. Hossain (1989). Genetic variability, correlation and path-coefficient analysis in watermelon. Bangladesh J. Plant Breed. Gen., 2(1,2): 31-35.

Mostafa, Y.A.M. (2006). The effect of some genetic and environmental factors on growth and yield of pumpkin (Cucurbita sp.). Ph.D. Thesis, Fac. Agric. Assuit Univ., Egypt.

Mukunda, L.M.; K. Haribabu and G.L.K. Reddy (2003). Genetic divergence in pumpkin. Indian J. Hort., 60(4): 363-367.

Olson, D.L.; J.R. Nechols and C.W. Marr (1995). Consumers' preference for insecticide-free pumpkins in eastern Kansas. Hort. Technology, 5: 274276.

Prasad, V.S. and D.P. Singh (1992). Estimate of heritability, genetic advance and association between yield and its components in cucumber (Cucumis sativus L.). Indian J. Hort., 49(1): 62-69.

Rana, T.K.; R.N. Vashistha and M.L. Pandita (1985). Correlation and coefficient studies in pumpkin. Haryana J. Hort. Sci., 14(1/2): 108-113.

Snedecor, G.W. and W.G. Cochran (1967). Statistical methods. $6^{\text {th }}$ ed. lowa State Univ. Press, Ames., lowa, U.S.A.

Swamy, K.R. and O.P. Dutta (1991). Coheritable variation in muskmelon (Cucumis melo L.). Indian J. Agric. Res., 25(3): 149-153.

Vallejo, C.F.A.; S.E.I. Estrada; G.D. Baena and D.M.A. Garcia (1999a). UNAPAL-Mandarino: new pumpkin, cucurbita maxima, cultivar adapted to valledel cuuca, Colombia ambient conditions. Acta Agronomica, Universidad Nacional de Colombia, 49(112):10-13, Colombia. (C.F. Plant Breed. Abst., 2001, 71(4): 4283).

Vallejo, C.F.A.; S.E.I. Estrada; G.D. Baena and D.M.A. Garcia (1999b). UNAPAL-Bolo Verd: new pumpkin cultivar, cucurbita moschata, adapted to valledel cauca, Colombia ambient conditions. Acta Agronomica, Universidad Nacional de Colombia, 49(314): 7-10, Colombia. (C.F. Plant Breed. Abst., 2001, 71(4): 4284). 
White, J.M. (2002). Pumpkin yield and size when grown on four plastic mulches as a second crop. Proc. Fla. State Hort. Soc., 115: 232-233.

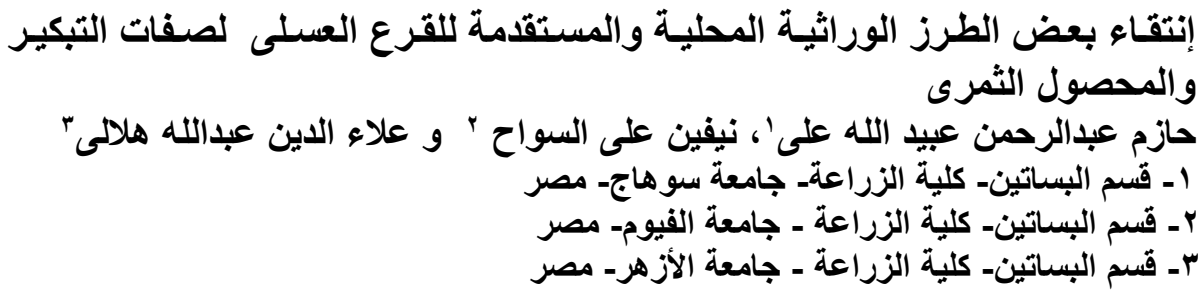

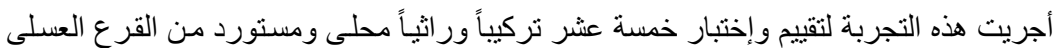

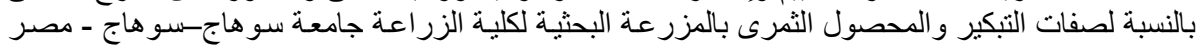

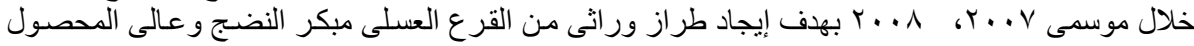
تحت ظروف جنوب الو ادى (منطقة مصر العليا). ويمكن تلخيص أهم النتائج فيما يلي:

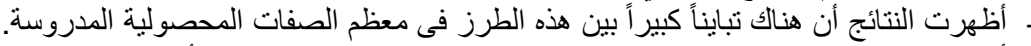

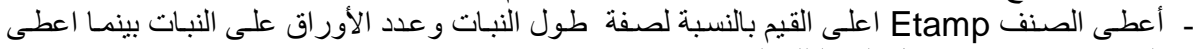
الصنف Butternut اقل القيم لتنلك الصفات.

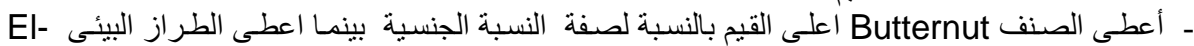
Mansoura

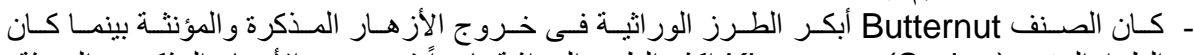

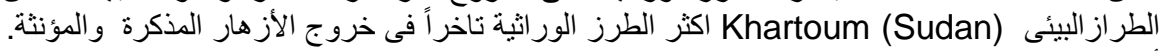

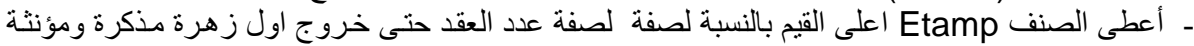

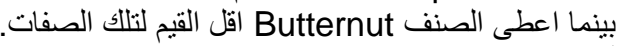

ـ أعطى الطراز البيئى Pepa (Beni Suef) اعلى القيم بالنسبة لصفة عدد العقد بين خروج اول زهرة

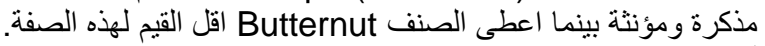

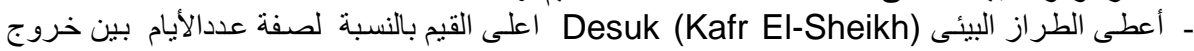

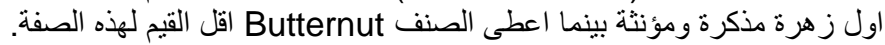
ـ ـ أعطى الصنف Etamp اعلى القيم بالنسبة لصفات وزن الثمرة , قطر الثمرة، سمك اللحم بينما أعطى الثي الصنف Butternut اقل القيم لتنلك الصفات.

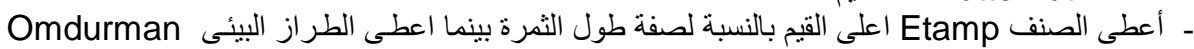
(audan)

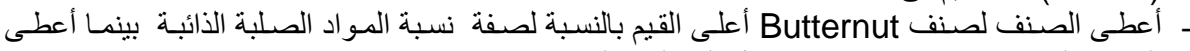
الطراز البيئى Bardis (Sohag القل القيم لهذه الصفة.

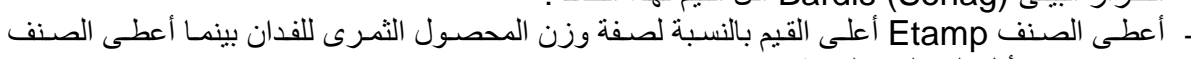
Butternut ومن هنا.... فإن نتائج هذة الدراسة تعتبر أداة فعالة فى برامج التربية لتحسين الطرز المحلية للقرع العسلى تحت ظروف منطقة مصر العليا. 
Table (1): Name, source and fruit characteristics of fifteen pumpkin genotypes grown at Faculty of Agriculture, Sohag University, EIKawser, Sohag.

\begin{tabular}{|l|c|c|c|c|c|c|}
\hline \multicolumn{1}{|c|}{ Name } & Source & Skin color & Flesh color & Fruit size & Fruit shape & Shell \\
\hline El-Kola (Sohag) & Local Egypt & Light Yellow & Yellow & Large $(>4 \mathrm{~kg})$ & Pyriform-globular & Semi-grooved \\
\hline Abu Tisht (Qena) & Local Egypt & Light Orange & Yellow & Large $(>4 \mathrm{~kg})$ & Pyriform-globular & Semi-grooved \\
\hline Bardis (Sohag) & Local Egypt & Green Yellow & Light yellow & Large $(>4 \mathrm{~kg})$ & Pyriform & Smooth \\
\hline Ismailia & Local Egypt & Yellow & Orange & Large $(>4 \mathrm{~kg})$ & Pyriform-globular & Semi-grooved \\
\hline Omdurman (Sudan) & Local Sudan & Dark Green & Deep Orange & Medium $(2-4 \mathrm{~kg})$ & Globular & Grooved \\
\hline Khartoum (Sudan) & Local Sudan & Light Green & Light yellow & Medium $(2-4 \mathrm{~kg})$ & Globular & Semi-grooved \\
\hline Kom Badar (Sohag) & Local Egypt & Dark Copper & Deep Orange & Medium $(2-4 \mathrm{~kg})$ & Globular & Grooved \\
\hline El-Edua (El-Minia) & Local Egypt & Yellow & Light yellow & Medium $(2-4 \mathrm{~kg})$ & Globular & Grooved \\
\hline Etamp & USA cv* & Yellow & Light yellow & Large $(>4 \mathrm{~kg})$ & Pyriform & Semi-grooved \\
\hline El-Mansoura & Local Egypt & Light Copper & Orange & Large $(>4 \mathrm{~kg})$ & Pyriform & Grooved \\
\hline El-Kanater (Kalubia) & Local Egypt & Light Yellow & Light yellow & Large $(>4 \mathrm{~kg})$ & Pyriform & Smooth \\
\hline Butternut & USA cv** & Copper & Yellow & Small $(<2 \mathrm{~kg})$ & Pyriform & Smooth \\
\hline Qus (Qena) & Local Egypt & Copper & Light orange & Small $(<2 \mathrm{~kg})$ & Pyriform & Semi-grooved \\
\hline Pepa (Beni Suef) & Local Egypt & Copper & Light orange & Medium $(2-4 \mathrm{~kg})$ & Pyriform & Semi-grooved \\
\hline Desuk (Kafr El-Sheikh) & Local Egypt & Copper & Light orange & Large $(>4 \mathrm{~kg})$ & Pyriform & Grooved \\
\hline
\end{tabular}

${ }^{*}$ From Prof. Dr. A.M. El-Damarany, Professor of Vegetable and Head of Department of Horticulture, Faculty of Agriculture, Sohag University, Sohag, Egypt.

**From Dr. Yahia A.M. Mostafa, Researcher at Cross pollinated Vegetable Research, Horticulture Research Institute, Agriculture Research Center, Giza 
Table (2): Vine length, Number of leaves/plant, Sex ratio, Number of days to $1^{\text {st }}$ male flower and number of nods to get the $1^{\text {st }}$ male flower for the fifteen pumpkin genotypes sown during 2007 and 2008 seasons.

\begin{tabular}{|c|c|c|c|c|c|c|c|c|c|c|}
\hline \multirow[t]{2}{*}{ Genotypes } & \multicolumn{2}{|c|}{$\begin{array}{l}\text { Vine length } \\
(\mathrm{m})\end{array}$} & \multicolumn{2}{|c|}{$\begin{array}{l}\text { Number of } \\
\text { leaves/plant }\end{array}$} & \multicolumn{2}{|c|}{$\begin{array}{c}\text { Sex ratio } \\
(\%)\end{array}$} & \multicolumn{2}{|c|}{$\begin{array}{l}\text { No. of days to first } \\
\text { male flower }\end{array}$} & \multicolumn{2}{|c|}{$\begin{array}{l}\text { No. of nods to get the } \\
\text { first male flower }\end{array}$} \\
\hline & 2007 & 2008 & 2007 & 2008 & 2007 & 2008 & 2007 & 2008 & 2007 & 2008 \\
\hline El-Kola (Sohag) & $4.69 \mathrm{~h}$ & $4.68 \mathrm{i}$ & $169.0 \mathrm{hi}$ & $168.0 \mathrm{hi}$ & 6.73 ef & 7.05 ef & 54.00 cde & $53.67 \mathrm{~cd}$ & $5.33 \mathrm{de}$ & $5.67 \mathrm{bc}$ \\
\hline Abu Tisht (Qena) & $4.45 \mathrm{i}$ & $4.46 \mathrm{j}$ & $185.0 \mathrm{e}$ & $184.0 \mathrm{e}$ & $8.08 \mathrm{~cd}$ & 7.82 bcde & $53.00 \mathrm{def}$ & $52.67 \mathrm{de}$ & $6.33 \mathrm{abc}$ & $6.00 \mathrm{bc}$ \\
\hline Bardis (Sohag) & $5.51 \mathrm{~b}$ & $5.52 \mathrm{~b}$ & $191.0 \mathrm{~d}$ & $190.0 \mathrm{~d}$ & $8.99 a b$ & $8.61 \mathrm{ab}$ & $52.67 \mathrm{efg}$ & 52.33 ef & $5.67 \mathrm{cde}$ & $6.00 \mathrm{bc}$ \\
\hline Ismailia & $4.83 \mathrm{f}$ & $4.82 \mathrm{f}$ & $182.0 \mathrm{f}$ & $181.0 \mathrm{f}$ & 6.81 ef & 7.17 def & $56.00 \mathrm{~b}$ & $55.67 \mathrm{~b}$ & 5.67 cde & $.33 \mathrm{c}$ \\
\hline Omdurman (Sudan) & 4.191 & $4.18 n$ & $133.0 \mathrm{k}$ & $134.0 \mathrm{k}$ & $8.51 \mathrm{bc}$ & $8.08 \mathrm{bcd}$ & $57.67 \mathrm{a}$ & $57.33 \mathrm{a}$ & 5.67 cde & $5.33 \mathrm{c}$ \\
\hline Khartour & $4.26 \mathrm{k}$ & $4.25 \mathrm{~m}$ & $135.0 \mathrm{k}$ & $135.0 \mathrm{k}$ & $7.92 \mathrm{~cd}$ & 7.52 cdef & $58.00 \mathrm{a}$ & $57.67 \mathrm{a}$ & $6.33 \mathrm{abc}$ & $6.00 \mathrm{bc}$ \\
\hline Kom Badar (Sohag) & $4.27 \mathrm{k}$ & 4.281 & $168.0 \mathrm{i}$ & $167.0 \mathrm{ij}$ & $7.64 \mathrm{~d}$ & 7.90 bcde & $51.67 \mathrm{fg}$ & $51.33 \mathrm{f}$ & $6.67 \mathrm{ab}$ & $6.33 \mathrm{~b}$ \\
\hline El-Edua (El-Minia) & $4.70 \mathrm{~h}$ & $4.71 \mathrm{~h}$ & $176.0 \mathrm{~g}$ & $177.0 \mathrm{~g}$ & $7.61 \mathrm{~d}$ & 7.32 cdef & $54.33 \mathrm{~cd}$ & $53.67 \mathrm{~cd}$ & 5.67 cde & $5.67 \mathrm{bc}$ \\
\hline Etamp & $5.66 \mathrm{a}$ & $5.67 \mathrm{a}$ & $221.0 \mathrm{a}$ & $221.0 \mathrm{a}$ & $8.11 \mathrm{~cd}$ & 7.76 bcde & $51.33 \mathrm{~g}$ & 51.67 ef & $7.00 \mathrm{a}$ & $7.33 \mathrm{a}$ \\
\hline El-Mansoura & $4.88 \mathrm{e}$ & $4.88 \mathrm{e}$ & $199.0 \mathrm{C}$ & $200.0 \mathrm{c}$ & $6.54 \mathrm{f}$ & $6.79 \mathrm{f}$ & $52.33 \mathrm{fg}$ & 52.00 ef & $5.67 \mathrm{cde}$ & $5.33 \mathrm{c}$ \\
\hline El-Kanater (Kalubia) & $4.76 \mathrm{~g}$ & $4.75 \mathrm{~g}$ & $165.0 \mathrm{j}$ & $165.0 \mathrm{j}$ & $7.88 \mathrm{~cd}$ & 7.53 cdef & 54.00 cde & $53.67 \mathrm{~cd}$ & $6.00 \mathrm{bcd}$ & $5.33 \mathrm{c}$ \\
\hline Butternut & $3.35 \mathrm{~m}$ & 3.350 & 128.01 & 127.01 & $9.70 \mathrm{a}$ & $9.41 \mathrm{a}$ & $45.33 \mathrm{~h}$ & $45.00 \mathrm{~g}$ & $4.33 \mathrm{f}$ & $4.00 \mathrm{~d}$ \\
\hline Qus (Qena) & $4.99 \mathrm{~d}$ & $5.00 \mathrm{~d}$ & $205.0 \mathrm{~b}$ & $206.0 \mathrm{~b}$ & $7.88 \mathrm{~cd}$ & $7.65 \mathrm{cdef}$ & $52.33 \mathrm{fg}$ & $52.67 \mathrm{de}$ & $5.33 \mathrm{de}$ & $5.33 \mathrm{c}$ \\
\hline Pepa (Beni Suef) & $4.36 \mathrm{j}$ & $4.37 \mathrm{k}$ & $171.0 \mathrm{~h}$ & $170.0 \mathrm{~h}$ & $8.52 \mathrm{bc}$ & $8.15 \mathrm{bc}$ & $54.67 \mathrm{c}$ & $54.33 \mathrm{c}$ & 5.00 ef & $5.33 \mathrm{c}$ \\
\hline Desuk (Kafr El-Sheikh) & $5.36 \mathrm{c}$ & $5.36 \mathrm{c}$ & $167.0 \mathrm{ij}$ & $166.0 \mathrm{ij}$ & $7.45 \mathrm{de}$ & 7.09 ef & $52.00 \mathrm{fg}$ & $51.33 \mathrm{f}$ & $5.67 \mathrm{cde}$ & $5.33 \mathrm{c}$ \\
\hline
\end{tabular}

* Means for accessions followed by the same letters are not significantly different at $5 \%$ level. 
Table (3): Number of days to $1^{\text {st }}$ female flower, Number of nods to get the $1^{\text {st }}$ female flower, Number of nods between $1^{\text {st }}$ male and $1^{\text {st }}$ female flower, Number of days between $1^{\text {st }}$ male and $1^{\text {st }}$ female flower and fruit weight for the fifteen pumpkin genotypes sown during 2007 and 2008 seasonss.

\begin{tabular}{|c|c|c|c|c|c|c|c|c|c|c|}
\hline \multirow[t]{2}{*}{ Genotypes } & \multicolumn{2}{|c|}{$\begin{array}{l}\text { No. of days to first } \\
\text { female flower }\end{array}$} & \multicolumn{2}{|c|}{$\begin{array}{c}\text { No. of nods to get } \\
\text { the first female } \\
\text { flower }\end{array}$} & \multicolumn{2}{|c|}{$\begin{array}{l}\text { No. of nods between } \\
1^{\text {st }} \text { male and } 1^{\text {st }} \\
\text { female flower }\end{array}$} & \multicolumn{2}{|c|}{$\begin{array}{c}\text { No. of days between } \\
1^{\text {st }} \text { male and } 1^{\text {st }} \\
\text { female flower }\end{array}$} & \multicolumn{2}{|c|}{$\begin{array}{c}\text { Fruit weight } \\
\text { (kg) }\end{array}$} \\
\hline & 2007 & 2008 & 2007 & 2008 & \begin{tabular}{|l|}
2007 \\
\end{tabular} & 2008 & 2007 & 2008 & 2007 & 2008 \\
\hline El-Kola (Sohag) & $58.00 \mathrm{~cd}$ & $58.33 \mathrm{~d}$ & $15.67 \mathrm{ef}$ & $15.33 \mathrm{fg}$ & $10.33 \mathrm{~cd}$ & $9.67 c$ & $4.00 \mathrm{bc}$ & $67 \mathrm{bcd}$ & $5.10 \mathrm{f}$ & $5.13 \mathrm{~g}$ \\
\hline Abu Tisht (Qena) & & & $\mathrm{bc}$ & $16.67 \mathrm{~cd}$ & 77 bcd & $10.67 \mathrm{abc}$ & & 3 cde & & \\
\hline Bardis (Sohag) & efg & 56.6 & def & $15.67 \mathrm{efg}$ & $3 \mathrm{~cd}$ & & & 3 cde & & \\
\hline Ismailia & & & bcd & cde & $b c$ & $a b$ & & $7 \mathrm{bc}$ & & \\
\hline Omdurman (Sudan) & & & 7 ef & & & $0 \mathrm{bc}$ & & 3 cde & & \\
\hline Khartoum (Sudan) & & & & $7 a b$ & & $37 \mathrm{a}$ & $4.67 \mathrm{bc}$ & $0 \mathrm{ab}$ & & $2.85 j$ \\
\hline Kom Badar (Sohag) & & $33 i$ & $\mathrm{bc}$ & $7 \mathrm{~cd}$ & $3 \mathrm{~cd}$ & $3 \mathrm{bc}$ & $3 \mathrm{bc}$ & $\mathrm{de}$ & $0 \mathrm{i}$ & $2.92 j$ \\
\hline El-Edua (El-Minia) & & & cde & 16.00 def & $10.67 \mathrm{bcd}$ & $10.33 \mathrm{bc}$ & $0 \mathrm{ab}$ & $a b$ & $3.76 \mathrm{~h}$ & $3.72 \mathrm{i}$ \\
\hline Etamp & $55.33 \mathrm{fg}$ & $55.67 \mathrm{hi}$ & & & $11.67 \mathrm{ab}$ & $11.00 \mathrm{ab}$ & $0 \mathrm{bc}$ & $4.00 \mathrm{de}$ & $9.80 \mathrm{a}$ & $9.90 \mathrm{a}$ \\
\hline El-Mansoura & 56.33 efg & $56.67 \mathrm{efg}$ & 16.00 def & $15.67 \mathrm{efg}$ & $10.33 \mathrm{~cd}$ & $10.33 \mathrm{bc}$ & $4.00 \mathrm{bc}$ & $4.67 \mathrm{bcd}$ & $6.05 \mathrm{e}$ & $6.08 \mathrm{e}$ \\
\hline El-Kanater (Kalubia) & 56.33 efg & $56.00 \mathrm{ghi}$ & 16.33 cde & $16.00 \mathrm{def}$ & $10.33 \mathrm{~cd}$ & $10.67 \mathrm{abc}$ & $2.33 \mathrm{c}$ & $2.33 \mathrm{f}$ & $5.23 \mathrm{f}$ & $5.31 \mathrm{f}$ \\
\hline Butternut & $43.00 \mathrm{~h}$ & $42.67 \mathrm{j}$ & $7.00 \mathrm{~g}$ & $6.67 \mathrm{~h}$ & $2.67 \mathrm{e}$ & $2.67 \mathrm{~d}$ & $2.33 \mathrm{c}$ & $2.33 \mathrm{f}$ & 1.081 & $1.12 \mathrm{~m}$ \\
\hline Qus (Qena) & $56.67 \mathrm{def}$ & $56.33 \mathrm{fgh}$ & 16.00 def & $16.33 \mathrm{cde}$ & $10.67 \mathrm{bcd}$ & $11.00 \mathrm{ab}$ & $4.33 \mathrm{bc}$ & $3.67 \mathrm{def}$ & $1.60 \mathrm{k}$ & 1.601 \\
\hline Pepa (Beni Suef) & $57.00 \mathrm{de}$ & $57.33 \mathrm{e}$ & $17.33 \mathrm{~b}$ & $17.00 \mathrm{bc}$ & $12.33 \mathrm{a}$ & $11.67 \mathrm{a}$ & $2.33 \mathrm{c}$ & 3.00 ef & $3.87 \mathrm{~h}$ & $3.82 \mathrm{i}$ \\
\hline Desuk (Kafr El-Sheikh) & $59.00 \mathrm{c}$ & $58.67 \mathrm{~d}$ & $15.33 \mathrm{f}$ & $15.00 \mathrm{~g}$ & $9.67 d$ & $9.67 \mathrm{c}$ & $7.00 \mathrm{a}$ & $7.33 \mathrm{a}$ & $6.55 \mathrm{~d}$ & $6.57 \mathrm{~d}$ \\
\hline
\end{tabular}

* Means for accessions followed by the same letters are not significantly different at $5 \%$ level. 
Table (4): Fruit length, Fruit diameter, Flesh thickness, Total soluble solids and Total fruit yield for the fifteen pumpkin genotypes sown during 2007and 2008 seasons.

\begin{tabular}{|c|c|c|c|c|c|c|c|c|c|c|}
\hline \multirow[t]{2}{*}{ Genotypes } & \multicolumn{2}{|c|}{$\begin{array}{l}\text { Fruit length } \\
\text { (cm) }\end{array}$} & \multicolumn{2}{|c|}{$\begin{array}{l}\text { Fruit diameter } \\
\text { (cm) }\end{array}$} & \multicolumn{2}{|c|}{$\begin{array}{l}\text { Flesh thickness } \\
\text { (cm) }\end{array}$} & \multicolumn{2}{|c|}{$\begin{array}{l}\text { TSS } \\
(\%)\end{array}$} & \multicolumn{2}{|c|}{$\begin{array}{l}\text { Total fruit yield } \\
\text { (Ton/feddan) }\end{array}$} \\
\hline & 2007 & 2008 & 2007 & 2008 & 2007 & 2008 & 2007 & 2008 & 2007 & 2008 \\
\hline El-Kola (Sohag) & $22.33 \mathrm{j}$ & $22.20 \mathrm{k}$ & $12.20 \mathrm{~m}$ & $12.17 \mid$ & $2.44 \mathrm{f}$ & $2.43 \mathrm{~g}$ & 4.681 & 4.661 & $26.80 \mathrm{e}$ & $26.47 \mathrm{e}$ \\
\hline Abu Tisht (Qena) & $34.27 \mathrm{e}$ & $34.12 \mathrm{e}$ & $20.80 \mathrm{~b}$ & $20.76 \mathrm{~b}$ & $2.34 \mathrm{~g}$ & $2.33 \mathrm{~h}$ & $5.45 \mathrm{~g}$ & $5.45 \mathrm{~g}$ & $29.58 \mathrm{c}$ & $29.24 \mathrm{c}$ \\
\hline Bardis (Sohag) & $41.40 \mathrm{~b}$ & $41.30 \mathrm{~b}$ & $20.13 c$ & $20.10 \mathrm{c}$ & $3.75 c$ & $3.73 \mathrm{~d}$ & $4.51 \mathrm{~m}$ & $4.49 \mathrm{~m}$ & $30.50 \mathrm{~b}$ & $30.17 \mathrm{bc}$ \\
\hline Ismailia & $22.70 \mathrm{ij}$ & $22.89 \mathrm{j}$ & $17.10 \mathrm{i}$ & $17.00 \mathrm{~h}$ & $2.41 \mathrm{fg}$ & $2.38 \mathrm{~g}$ & $5.82 \mathrm{f}$ & $5.83 \mathrm{f}$ & $26.64 \mathrm{e}$ & $26.31 \mathrm{e}$ \\
\hline Omdurman (Sudan) & $13.16 \mathrm{~m}$ & $13.10 n$ & $17.72 \mathrm{~h}$ & $17.52 \mathrm{~g}$ & $2.15 \mathrm{i}$ & $2.14 \mathrm{j}$ & $5.18 \mathrm{j}$ & $5.17 \mathrm{j}$ & $13.93 \mathrm{k}$ & $13.67 \mathrm{k}$ \\
\hline Khartoum (Sudan) & $20.20 \mathrm{k}$ & 20.181 & $14.45 \mathrm{I}$ & $14.35 \mathrm{k}$ & $2.12 \mathrm{i}$ & $2.13 j$ & $5.05 \mathrm{k}$ & $5.06 \mathrm{k}$ & $14.73 \mathrm{j}$ & $14.77 j$ \\
\hline Kom Badar (Sohag) & 19.001 & $18.83 \mathrm{~m}$ & $15.13 \mathrm{k}$ & $15.08 j$ & $2.13 \mathrm{i}$ & $2.12 j$ & $5.27 i$ & $5.26 \mathrm{i}$ & $20.01 \mathrm{~h}$ & $19.68 \mathrm{~h}$ \\
\hline El-Edua (EI-Minia) & $23.36 \mathrm{i}$ & $23.30 \mathrm{j}$ & $18.11 \mathrm{gh}$ & $18.11 \mathrm{f}$ & $2.25 d$ & $2.24 i$ & $6.42 \mathrm{~b}$ & $6.42 \mathrm{~b}$ & $18.11 \mathrm{i}$ & $18.44 \mathrm{i}$ \\
\hline Etamp & $51.25 \mathrm{a}$ & $51.14 \mathrm{a}$ & $28.23 \mathrm{a}$ & $28.20 \mathrm{a}$ & $4.15 \mathrm{a}$ & $4.17 \mathrm{a}$ & 4.691 & $4.67 \mid$ & $39.49 \mathrm{a}$ & $39.61 \mathrm{a}$ \\
\hline El-Mansoura & $39.03 \mathrm{~d}$ & $39.37 \mathrm{~d}$ & $16.25 j$ & $16.22 \mathrm{i}$ & $3.97 \mathrm{~b}$ & $3.96 \mathrm{c}$ & $6.21 \mathrm{c}$ & $6.22 \mathrm{c}$ & $23.41 \mathrm{f}$ & $23.45 \mathrm{f}$ \\
\hline El-Kanater (Kalubia) & $40.20 \mathrm{c}$ & $40.13 \mathrm{c}$ & $19.36 \mathrm{~d}$ & $19.30 \mathrm{~d}$ & $3.35 d$ & $3.34 \mathrm{e}$ & $5.18 j$ & $5.19 j$ & $21.74 \mathrm{~g}$ & $21.41 \mathrm{~g}$ \\
\hline Butternut & $24.30 \mathrm{~h}$ & $24.37 \mathrm{i}$ & $12.09 \mathrm{~m}$ & $12.14 \mathrm{I}$ & $1.95 \mathrm{j}$ & $1.94 \mathrm{k}$ & $6.68 \mathrm{a}$ & $6.67 \mathrm{a}$ & 5.181 & $4.85 I$ \\
\hline Qus (Qena) & $25.10 \mathrm{~h}$ & $25.03 \mathrm{~h}$ & $18.30 \mathrm{fg}$ & $18.27 \mathrm{ef}$ & $3.25 \mathrm{e}$ & $3.24 \mathrm{f}$ & $5.95 \mathrm{e}$ & $5.96 \mathrm{e}$ & $30.65 \mathrm{~b}$ & $30.31 \mathrm{~b}$ \\
\hline Pepa (Beni Suef) & $31.50 \mathrm{f}$ & $31.27 f$ & 18.70 ef & $18.67 \mathrm{e}$ & $4.12 \mathrm{a}$ & $4.13 \mathrm{ab}$ & $5.35 \mathrm{~h}$ & $5.35 \mathrm{~h}$ & $14.13 \mathrm{jk}$ & $13.80 \mathrm{k}$ \\
\hline Desuk (Kafr El-Sheikh) & $29.33 \mathrm{~g}$ & $29.20 \mathrm{q}$ & $19.03 \mathrm{de}$ & $19.15 d$ & $4.11 \mathrm{a}$ & $4.10 \mathrm{~b}$ & $6.17 \mathrm{~d}$ & $6.18 \mathrm{~d}$ & $28.51 \mathrm{~d}$ & $28.18 d$ \\
\hline
\end{tabular}

* Means for accessions followed by the same letters are not significantly different at $5 \%$ level. 

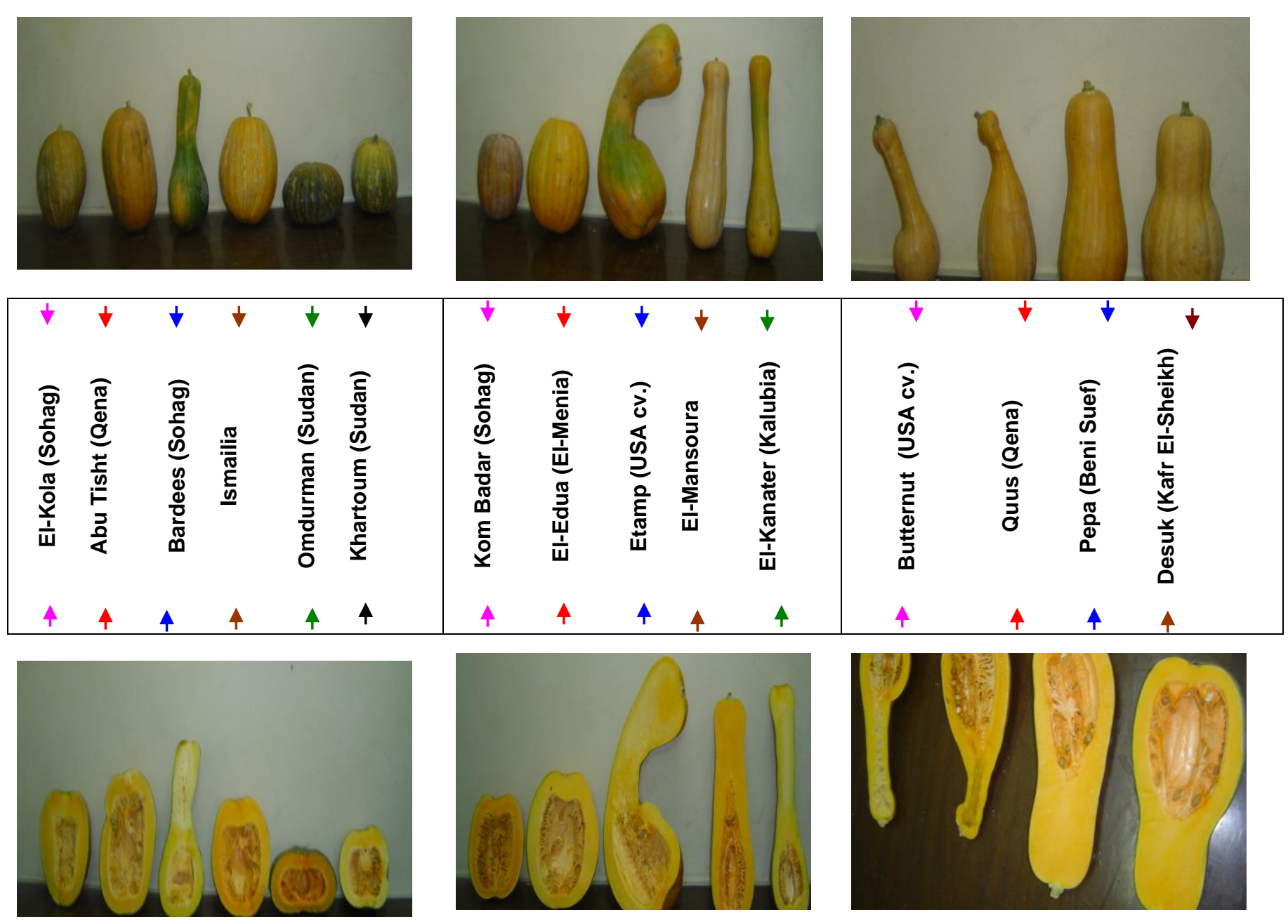
Obiadalla-Ali, H. A. et al. 